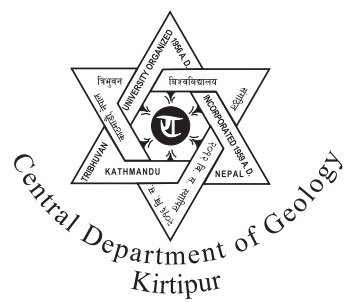

\title{
Late Pleistocene plant macro-fossils from the Gokarna Formation of the Kathmandu Valley, Central Nepal
}

\author{
*Sudarshan Bhandari ${ }^{1}$, Arata Momohara ${ }^{2}$ and Khum N. Paudayal ${ }^{1}$ \\ ${ }^{1}$ Central Department of Geology, Tribhuvan University, Kirtipur, Kathmandu, Nepal \\ ${ }^{2}$ Faculty of Horticulture, Chiba University, Matsudo 648, Chiba 271-8510, Japan
}

\begin{abstract}
The Kathmandu Valley offers the best archive to study the Late Pleistocene climate in Nepal. The Gokarna Formation, constituting the middle part of the sedimentary sequence of the Kathmandu Valley comprises alternating layers of carbonaceous clay, silt, massive to parallel and large scale cross stratified, fine to coarse grained sands and occasional gravel layers, deposited at fluvio-deltaic and lacustrine environment. The organic rich layers of clay, silt, silty-sand and micaceous fine sand consists of abundant plant macro-fossils (fruit, seed and leaves). Plant macrofossils assemblage from the Gokarna Formation (thickness 28.5 $\mathrm{m}$, Dhapasi section) in the northern part of the valley consists of 56 taxa from 35 families. Depending upon the available plant, seven macrofossil assemblages, DS-I to DS-VII in ascending order were established. The common tree and shrubs discovered from this section were Eurya, Ficus, Carpinus, Quercus, Alnus, Rubus, Pyracantha, Zizyphus, Carpinus, Boehmeria etc. Carex, Scirpus triqueter, Scirpus, Polygonum, Euphorbia, Oxalis, Mosla, Viola etc. were the common herbaceous taxa. The constant occurrence of subtropical and warm temperate taxa including Eurya, Ficus, Pyracantha and Zizyphus indicated that subtropical and warm temperate climate continued during the deposition of those macrofossil assemblages. However change in the constituents of those taxa and occurrence of taxa indicating cooler climatic condition like conifers and Betula may indicate minor fluctuation of climate during the deposition of the Gokarna Formation.
\end{abstract}

\section{INTRODUCTION}

The Kathmandu Valley is one of the large intermontane basins formed within the Lesser Himalaya of Nepal. The basin is filled with fluvial and lacustrine sediments of more than $500 \mathrm{~m}$ thickness having early late Pliocene to Holocene age (Yoshida and Igarashi 1984; Sakai et al. 2001). The palynological investigations in the basin were undertaken by Igarashi et al. (1988), Nakagawa et al. (1996), Fujii and Sakai (2001), Paudayal and Ferguson (2004), and Paudayal $(2005,2006)$ but no major study of the plant macro fossils had been carried out although

*Corresponding author:

E-mail address: bhandari_sudarshan@hotmail.com the sediments outcropped in the Valley included wellpreserved plant macrofossils. Seed and fruits are the most valuable indicators for climate and vegetation of the past as pollen because with the help of them it is possible to get a complete, detailed and more accurate picture of the local vegetation and climate. We found an excellent outcrop in the northern part of the Valley containing abundant plant macrofossils within the Gokarna Formation. Many plant taxa included in the assemblages were not represented in earlier palynological studies and considered to add more detailed information for the reconstruction of paleovegetation and paleoclimate. In addition with the climatic implication, those taxa identified with genus and species level should clarify phytogeographical history of the basin that is situated 
in the boundary of three floristic provinces, SinoJapanese, Asia-Malaysian, and Irano-Turranean provinces (Takhtajan 1986). We have described plant macrofossils to reconstruct the paleovegetation and paleoclimate preliminary in this paper.

\section{GEOLOGICAL SETTINGS}

The geological, geomorphological and sedimentological investigations have divided the fluvio-deltaic and lacustrine sediments of the Kathmandu Valley into several formations. (Yoshida and Igarashi 1984; Dangol 1985; Yoshida and Gautam 1988; Sakai 2001). For the present study, we basically follow the classification proposed by Yoshida and Igarashi (1984) for the northern part of the basin, who studied the stratigraphy of this area in detail. The Lukundol Formation is the oldest lake sediments and is deposited around the southern part of the basin. By the prominent upliftment of the Himalaya the original lake shifted from south to north which resulted in the formation of three terrace deposits (Pyanggaon, Chapagaon and Boregaon) in the south.

The Gokarna, Thimi and Patan Formations, in ascending order are the younger lake sediments deposited in the central and northern part of the basin. The Gokarna Formation is characterised by alternating

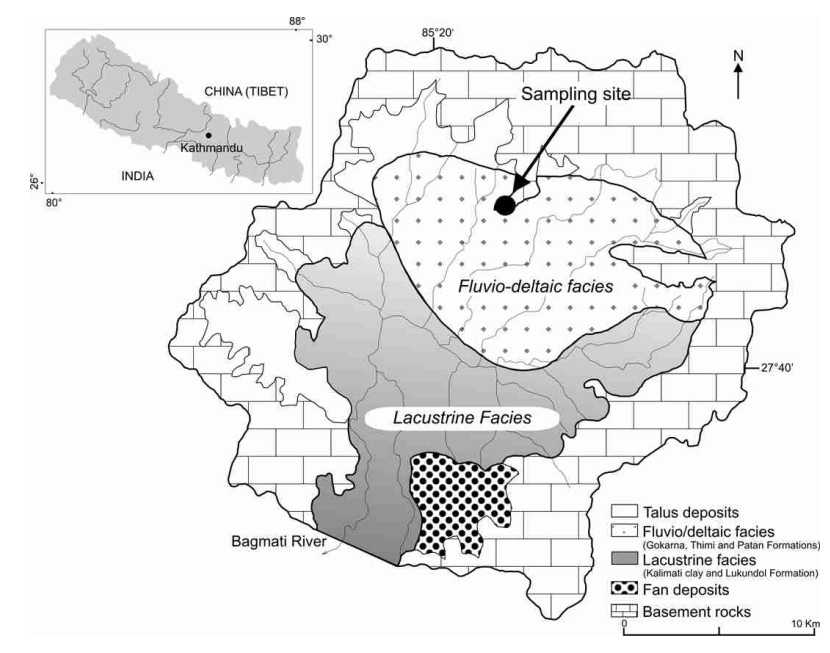

Fig. 1 Geological map of the Kathmandu valley (Redrawn after Yoshida and Igarashi 1984; Sakai et al. 2001) with the sample location within the Gokarna Formation. layers of carbonaceous clay, silt, massive to parallel and large scale cross stratified, fine to coarse grained sands and occasional gravel layers deposited at fluviodeltaic and lacustrine environment. This Formation is well exposed at a section in Dhapasi $\left(27^{\circ} 44^{\prime} 50^{\prime \prime} \mathrm{N}\right.$ and $85^{\circ} 19^{\prime} 45^{\prime \prime} \mathrm{E}$ ) at an altitude of $1345 \mathrm{~m}$ in the northern part of the Kathmandu Valley (Fig. 1). The thickness of this section is $28.5 \mathrm{~m}$ and composed of alternating layers of clay, silt and sand. The thickness of the clay beds ranges from 0.3 to $4 \mathrm{~m}$ and is covered by sand and gravel layers. The sand layers are massive, parallel or cross stratified, fine to coarse grained with occasional gravel layers (Fig 2). These sediments can be subdivided into cross-stratified sand beds of delta front facies, black sandy silt of pro-delta facies and parallel or trough cross stratified gravelly sand of fluvial channel facies (Gajurel et al. 2007). The radiocarbon ages of the Dhapasi section of the Gokarna Formation from a lower and upper layer were $>36,100$ and $>49,000$ years BP, respectively (Paudayal and Fergusson 2004; Paudayal 2006). The erranous dating result may be due to reworked samples.

\section{MODERN FLORA IN KATHMANDU VALLEY}

The Kathmandu Valley is located at the border of three floristic provinces: the Eastern Asiatic Province in the east, Irano-Turranean Province in the west and Indian Floristic Provinces in the south (Takhtajan, 1986). These floral provinces correspond with three different vegetation types, lucidophyllous forests, step and alpine grassland and tropical forests, which are developed under different climatic parameters respectively. In addition, vertical change of vegetation is conspicuous in the north facing as well as south facing slopes of the mountains surrounding the valley (Stainton 1972).

The vegetation of the valley floor of the Kathmandu is characterised by Schima-Castanopsis forest. In the recent decades, the forest of the valley floor were disturbed and destroyed by the human settlement. Small patches of stretched forest are present in some of the areas like Pashupati, Gokarna, Swayambhu, Hattiban, Nagarjun areas. In the mountain slope between $1800 \mathrm{~m}$ and $2700 \mathrm{~m}$, Quercus is dominant (Stainton 1972; Malla et al. 1976). The 

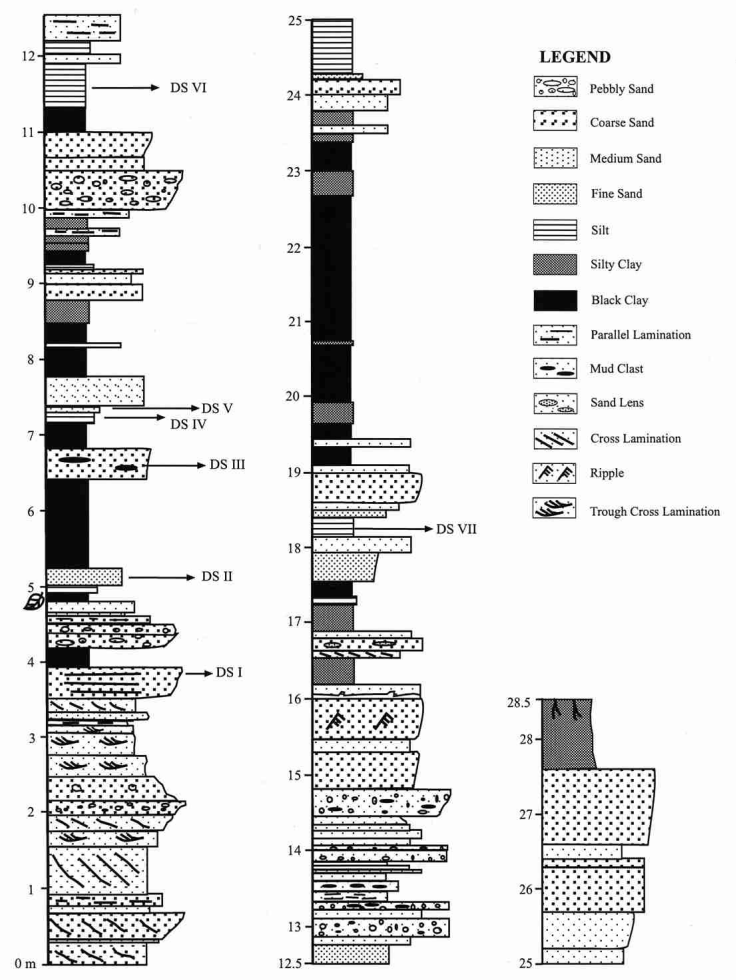

Fig. 2 Detailed lithostratigraphy of the Gokarna Formation at Dhapasi.

coniferous trees such as Abies, Tsuga and Picea are rarely distributed around the top of the mountains surrounding the valley. Pinus roxburghii is distributed in lowland region up to $2000 \mathrm{~m}$ whereas Pinus wallichiana is distributed in more than $1900 \mathrm{~m}$. The other floral elements in this area along with Quercus are Rhododendron, Pieris, Lyonia, Lithocarpus, Lindera, Carpinus, Symplocos, Acer etc. Alnus is distributed along gullies and wet ravines (Paudayal 2002).

\section{MATERIALS AND ANALYTICAL METHODS}

For the study of macrofossils, organic rich lamina or bed is selected for the extraction of samples. Generally macrofossils are preserved in organic rich sand and silt layers rather than in clay layers. About
5 kilogram sample was taken from each macrofossil assemblage and was washed and sieved in a $0.5 \mathrm{~mm}$ sieve to remove inorganic particles from plant fragments. The residue on $0.5 \mathrm{~mm}$ sieve was again sorted in water by sieves of different size ( $4 \mathrm{~mm}, 2$ $\mathrm{mm}$ and $1 \mathrm{~mm}$ ) to facilitate observation. The material was studied under binocular microscope of x100 magnifications and plant parts were picked up using brush and needle. The fossil were sorted into different vials by taxon and preserved in $70 \%$ ethanol.

For SEM (Scanning Electron Microscope) observation, the fruit and seed samples were washed with distilled water and dehydrated in the following series: 70\% ethanol for 3 hours, mixed 99\% ethanol and $99 \%$ butanol solution for 3 hours, and 100\% butanol for 24 hours and these samples were left for a week to evaporate solvent completely from them. After the complete evaporation of solvent from the samples, they were attached on sample levels with double stick tape and coated by platinum for 5-8 minutes or more. SEM observation was done under different magnifications.

Fossil leaves were separated from the sediments with the help of hydrogen peroxide $\left(\mathrm{H}_{2} \mathrm{O}_{2}\right)$ or sodium hydroxide $(\mathrm{NaOH})$ solution. The leaf compressions were bleached in sodium hypochlorite $(\mathrm{NaClO})$ solution to study the venation pattern (Worobiec 2003). The fossil leaves were pinched in plastic films and preserved in $70 \%$ ethanol.

\section{DESCRIPTION OF PLANT MACROFOSSILS}

Among 56 taxa discovered from the Dhapasi section, 52 taxa are displayed in Fig. 3, 4 and 5. The taxa are arranged and descibed in the alphabetical order on the basis of family. The ecology of the listed taxa are referred from Malla et al. (1986) and Press et al. (2000).

\section{Gymnosperms}

\section{Pinaceae}

Abies sp.

Material studied: Leaf. The lamina is flattened, $4.5 \mathrm{~mm}$ long and $1.4 \mathrm{~mm}$ wide, with distinct mid rib. Sessile, typically constricted and often twisted above the somewhat broadened base. Ecology: Common 
species in coniferous forest in an altitude of $2100-4400 \mathrm{~m}$.

\section{Tsuga sp.}

Material studied: Leaf. The lamina is flattened and lorate, $2.5 \mathrm{~mm}$ long and $0.7 \mathrm{~mm}$ wide with distinct mid rib and the petiole is $1 \mathrm{~mm}$ long and twisted at the base of the lamina. Ecology: Common species in coniferous forest in an altitude of 2100-3600 m.

\section{Angiosperms}

\section{Actinidiaceae}

\section{Actinidia sp.}

Material studied: Seed. The anatropous seed is elliptic, $1.5 \mathrm{~mm}$ long, $1 \mathrm{~mm}$ broad, composed of large cuboid cells with more of less hexagonal facets. The cells are arranged in about 15 rows transversly in the widest width. The inner surface of a seed has a polygonal pattern with slight depressions indicating the position of the anticlinal walls. Ecology: Occurs on mountain forest and forest border.

\section{Betulaceae}

\section{Alnus sp.}

Material studied: Fruiting scale of infructescence. The fruiting scale is fan-shaped, $2.5 \mathrm{~mm}$ long, $2.0 \mathrm{~mm}$ wide, woody and thick. The uppermost fringe of the scale is somewhat thickened and consists of some very low lobes. Adaxial surface of the scale is striate longitudinally. Ecology: Wetland and secondary forest.

\section{Betula sp.}

Material studied: Fruiting scale infructescence

The fruiting scale of Betula is fan-shaped as similar as the scale of Alnus. The size of the scale is $2.0 \mathrm{~mm}$ long and $2.0 \mathrm{~mm}$ wide. The uppermost fringe of the scale is thinner and more flattened than Alnus. The fringe consists of three wing-like lobes. Ecology: Part of the wetland forest but commonly found in coniferous forest.

\section{Carpinus sp.}

Material studied: Nut. The nut is ovate in outline and lenticular in transverse section, $2.6 \mathrm{~mm}$ long and 1.5 $\mathrm{mm}$ wide, with three or more vertical ridges. It is subtended by a large unilaterally 3-lobed involucre. Ecology: Occurs in temperate forest.

\section{Cucurbitaceae}

\section{Gen. Indet.}

Material studied: Seed. The seed is obovoid, 4.0 $\mathrm{mm}$ long, $2.3 \mathrm{~mm}$ broad, laterally flattened in structure. The base is obtuse to truncate. Surface is dull, woody, roughened with irregular ridges and knobs. Edge of the seed sometimes with a conspicuous ridge, delimited by distinct groove. Ecology: Occurs on shady places.

\section{Cyperaceae}

\section{Carex sp.}

Material studied: Fruit. The fruit is biconvex in cross section and obovate in lateral view, $1.7 \mathrm{~mm}$ long, $0.7 \mathrm{~mm}$ wide, narrow tapering towards base and apex. The wall is coriaceous or spongy. Ecology: Streamside and marshy vegetation.

\section{Eleocharis sp.}

Material studied: Fruit. The fruit is obovate in outline, $2.0 \mathrm{~mm}$ long and $1.5 \mathrm{~mm}$ wide, biconvex and flattened with traces of stylocarp. The wall is ligneous, lusterless and woody. The greatest width is in the middle part of the nutlet. Ecology: Streamside and marshy vegetation.

\section{Scirpus triqueter}

Material studied: Fruit. The fruit is biconvex with a very fine cellular pattern. The shape is circular to ovate with rounded base, $2.0 \mathrm{~mm}$ long, $1.2 \mathrm{~mm}$ wide. The largest width is in the middle part of the fruit. Bristles are sometimes present in some of the fossils. Ecology: Streamside and marshy vegetation.

\section{Scirpus sp.}

Material studied: Fruit. The fruit is flat to lenticular and obovate, $2.0 \mathrm{~mm}$ long, $1.5 \mathrm{~mm}$ wide. Some of the fossils have remains of bristles at the base. The number of bristles ranges between $6-8$. The base cuneatly narrowed. The surface consists of an epidermis with longitudinal rows of cells. The lower layer of the wall of the fruits are formed by longitudinally arranged schlerenchymatous fibres and is coriaceous; surface glabrous, lusterless. Ecology: Streamside and marshy vegetation. 


\section{Euphorbiaceae}

\section{Acalypha sp.}

Material studied: Seed. The seed is ovoid to compressed ellipsoid, fine striations in the seed wall, $1.5 \mathrm{~mm}$ long, $1.0 \mathrm{~mm}$ broad, black. Chalazal area circular, raphe visible as a longitudinal pale suture running from funicle to chalazal area. Ecology: Occurs on open and dry places.

\section{Euphorbia sp.}

Material studied: Seed. The seed is ellipsoidobovoid, $3.1 \mathrm{~mm}$ long, $2.8 \mathrm{~mm}$ wide, surface dull to lustrous, smooth, strongly reticulate, chalazal area circular, raphe distinct, ventral and visible as a longitudinal pale suture running from chalazal area to funicle. Ecology: Occurs on open and dry places.

\section{Fagaceae}

\section{Quercus cf. Cyclobalanopsis}

Material studied: Fruit. The fruit is globose to subcylindric in outline and brown or yellowish in colour, $11.0 \mathrm{~mm}$ long and $6.5 \mathrm{~mm}$ wide, enveloped at base by a cup shaped involucre. Some longitudinal striations are present on the acorn with distinctive cupules. The cupules are smooth and bear rings of scales which is the characteristic feature of Cyclobalanopsis. In some of the complete fruits, the cupules cover half of the seed. Ecology: Subtropical to temperate forest mixed with Pinus and Rhododendron.

\section{Gen. Indet.}

Material studied: Leaf (incomplete). The basal half of lamina, $47.0 \mathrm{~mm}$ in length and $37.0 \mathrm{~mm}$ in maximum width, is symmetrical and petiolate with serrated margin. Venation is simple craspedodromous with distinct and strait primary vein and the secondary veins are parallel to one another and curving up uniformely towards the leaf margin. Tertiary veins are parallel to one another. Ecology: Component of evergreen vegetation.

\section{Haloragaceae}

\section{Myriophyllum sp.}

Material studied: Endocarp. The endocarp is ovate in outline, $2.0 \mathrm{~mm}$ long, $1.3 \mathrm{~mm}$ broad, edge between dorsal and lateral surface is obtuse to angular. The external appearance of the surface is dull, glabrous. Outer margins fringed with tooth like processes. Generally the seeds are open at one end. Ecology: Aquatic vegetation.

\section{Hypoxidaceae}

\section{Hypoxis aurea}

Material studied: Seed. The seed is subglobose, $1.5 \mathrm{~mm}$ long, $1.3 \mathrm{~mm}$ broad, lusterless, rough, covered closely with papillae or tooth like projections and commonly with handle like structure. Ecology: Grassland vegetation.

\section{Labiatae}

\section{Lycopus sp.}

Material studied: Fruit. The fruit is oblong-ovoid and compressed to triangular, $1.2 \mathrm{~mm}$ long and 0.6 $\mathrm{mm}$ broad. Small, white mouth at the base with the rounded apex. The external appearance is brown black with woody surface. Ecology: Part of open vegetations on river banks.

\section{Mosla sp.}

Material studied: Fruit.The fruit is rounded to triangular, $1.4 \mathrm{~mm}$ long, $1.2 \mathrm{~mm}$ wide and $1 \mathrm{~mm}$ thick. The outer surface is woody, lusterless and finely reticulated with some thin white band like structure. Ecology: Occurs on shady and moist places.

\section{Perilla sp.}

Material studied: Fruit. The fruit is very much similar to Mosla in shape and outer structure. Rounded to triangular, $2.0 \mathrm{~mm}$ long, $1.8 \mathrm{~mm}$ wide and $1.4 \mathrm{~mm}$ thick. Fine and minute reticulation on the yellow outer surface. Woody Ecology: Occurs on shady and moist places.

\section{Magnoliaceae}

\section{Magnolia sp.}

Material studied: Seed. The seed is broad ovate in outline, $5.2 \mathrm{~mm}$ long and $4.3 \mathrm{~mm}$ wide, asymmetrical, low lengthwise ridge or shallow groove in the middle of a face and a small hole at the broader end. Wall somewhat bony. Outer surface almost smooth, with an elongate median raphe on the ventral side. Ecology: Constituent of the bottomland wetland forest. 

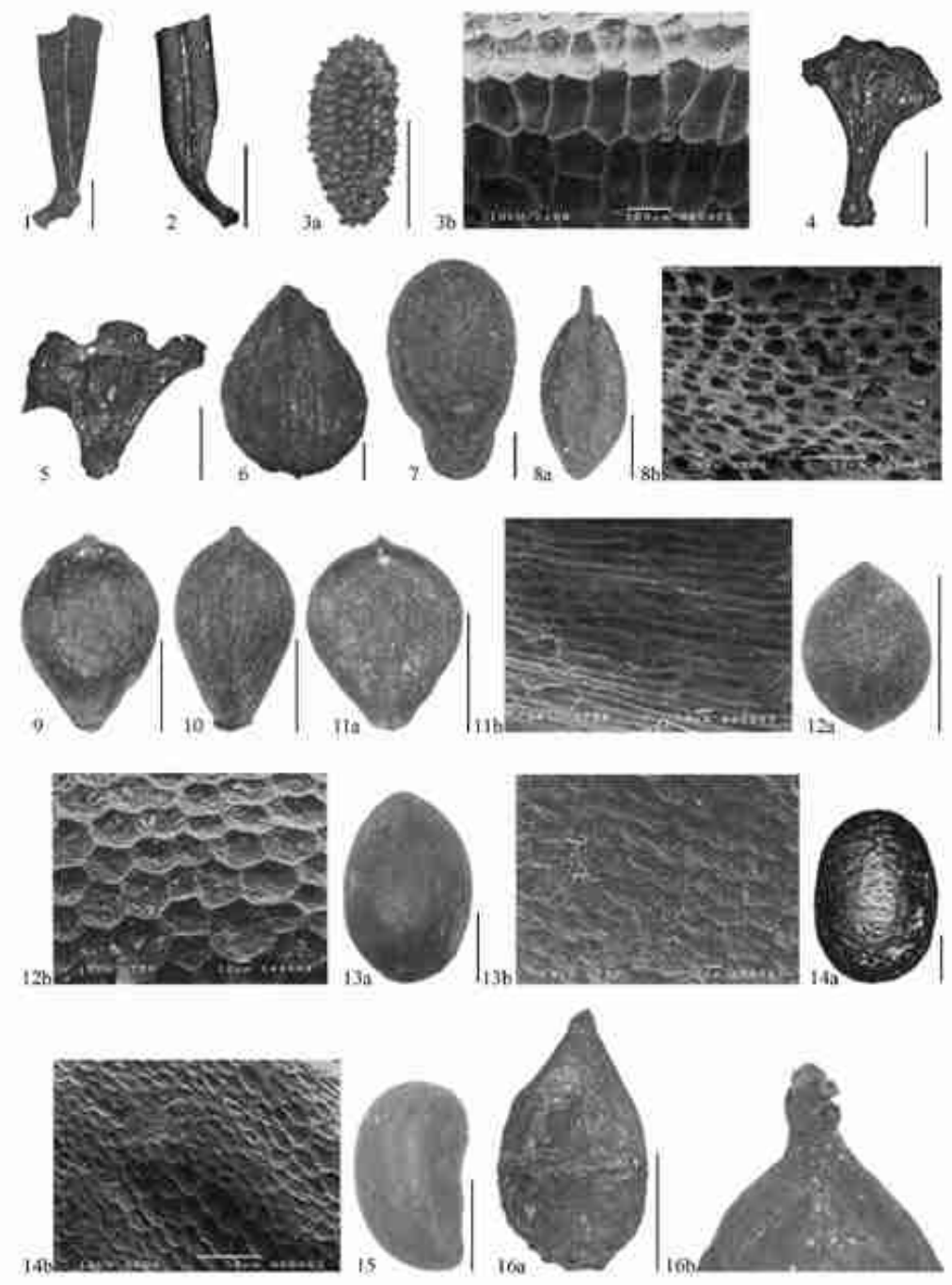

Scale 1-15: 1mm, 16 :5mm

Fig. 3: 1. Abies sp. (leaf), 2. Tsuga sp. (leaf), 3. Actinidia sp. (seed), 4. Alnus sp. (fruiting scale), 5. Betula sp. (fruiting scale), 6. Carpinus sp. (nutlet), 7. Cucurbitaceae (seed), 8. Carex sp. (fruit), 9. Eleocharis sp. (fruit), 10. Scirpus triqueter (fruit), 11. Scirpus sp. (fruit), 12. Acalypha sp. (seed), 13. Euphorbia sp. (seed), 14. Euphorbia sp. (seed), 15. Phyllanthus (seed), 16. Quercus cf. cyclobalanopsis (fruit)

\section{Menispermaceae}

\section{Stephania sp.}

Material studied: Endocarp.The endocarp is large, flat, more or less circular with dentate ridges on the outer periphery. The surface is woody and lusterless. The characteristic feature of this species is the presence of a hole in the middle part of the endocarp. Ecology: Occurs in mixed broad leaved forest or in sunny places.

\section{Moraceae}

\section{Ficus sp.}

Material studied: Endocarp. The endocarp is globose or ovate in outline, $1.3 \mathrm{~mm}$ long and $0.9 \mathrm{~mm}$ broad, apex slightly acute and base obtusely rounded. The surface of endocarp is composed of hexagonal or irregularly pentagonal to polygonal cells and each cell has a central deepening and several prominent foldings. Ecology: Occurs on open exposed places.

\section{Oxalidaceae}

\section{Oxalis sp.}

Material studied: Seed. The seed is ellipsoidobovoid, $1.5 \mathrm{~mm}$ long, $0.9 \mathrm{~mm}$ wide, laterally flattened, apex obtuse, base acute. The surface of the seed is transversely ribbed. The ribs are irregular and varies in number between 6 and 10. Ecology: Occurs in moist and shady places. 


\section{Polygonaceae}

\section{Persicaria nepalense}

Material studied: Fruit. The nutlet or fruit is ovate in outline and flattish, $2 \mathrm{~mm}$ long, $1.5 \mathrm{~mm}$ wide. The apex is somewhat abruptly pointed, base is slightly tapering. The whole structure is plano-convex. The surface is rough with fine sculpture and barely lustrous. Ecology: Stream side vegetation.

\section{Polygonum sp.}

Material studied: Fruit. The fruit-one seeded nuts, generally triangular in outline, $2.5 \mathrm{~mm}$ long, $1.5 \mathrm{~mm}$ wide, more rarely two sided. The fruit wall is formed from cuboidal or columnar sclereids with strongly thickened and often undulate walls. The side of the surface is slightly concave and the apex is sub-acute. The wall ligneous and the surface is rough and lusterless. Ecology: Stream side vegetation.

\section{Ranunculaceae}

\section{Ranunculus sp.}

Material studied: Fruit. The shape of the fruit is obovate, $1.8 \mathrm{~mm}$ long, $1.4 \mathrm{~mm}$ wide, with a thickened margin. The base of the style protrudes to a blunt spine. The surface structure is rough, indistinctly reticulate, ribbed, granulate on the flat sides with a margin of different shaped cells along the narrow edges of the flattened fruit. Ecology: Occurs on open moist place.

\section{Thalictrum sp.}

Material studied: Fruit. The fruit is a one seeded nutlet with several longitudinal ribs which are edged faintly. It is elliptic in lateral view having acute apex, $2.3 \mathrm{~mm}$ long, $1.2 \mathrm{~mm}$ broad. The base is slightly stipitate and the stipe is $0.2 \mathrm{~mm}$ long. Style is terminal, erect or slightly curved. The outer surface is glabrous, lusterless. Ecology: occurs in moist, shady as well as sunny places.

\section{Rhamnaceae}

\section{Zizyphus sp.}

Material studied: Endocarp. The endocarp is ovoid, stony with $10.0 \mathrm{~mm}$ length and $6.9 \mathrm{~mm}$ width. The surface is covered by thick walled reticulate ribs with hexagonal cells. The outer surface is lusterless and woody. Ecology: Subtropical to warm sunny places.

\section{Rosaceae}

\section{Prunus sp.}

Material studied: Endocarp. The endocarp is woody and ovate in outline, $11.5 \mathrm{~mm}$ in length and $8.0 \mathrm{~mm}$ in width, with several thick faint ridges arising from the base. These thick faint ridges branched into secondary and tertiary ridges and they anastomose obliquely towards the apex. Ecology: Common taxa in mixed and oak forest.

\section{Pyracantha sp.}

Material studied: Endocarp. The endocarp is one loculed, $2.5 \mathrm{~mm}$ long and $1.5 \mathrm{~mm}$ wide, with straight ventral margin and semi-circular dorsal margin. It is slightly pointed at the base and usually retuse at the base of the style. Ecology: Occurs on dry places.

\section{Rubus sp.}

Material studied: Endocarp. The endocarp is elliptic or ovate in outline and laterally flattened, $2.5 \mathrm{~mm}$ long and $1.5 \mathrm{~mm}$ wide. The base is rounded and the apex is bluntly narrowed and slightly curved towards ventral side. The dorsal side is convex and the ventral side is concave near the apex. The endocarp surface is reticulate with thick ribs and elongated concave interspaces of reticulum. Ecology: Occurs in moist as well as sunny places.

\section{Rutaceae}

\section{Gen. Indet.}

Material studied: Seed. The seeds are dark brown to black, $5.7 \mathrm{~mm}$ long and $3.3 \mathrm{~mm}$ broad, campylotropous and thick walled with concave ventral surface and curved dorsal surface. The outer surface is smooth and lustrous. Ecology: Subtropical to temperate forest.

\section{Sabiaceae}

\section{Meliosma sp.}

Material studied: Endocarp. The endocarp is subglobose and obovate in lateral view, $4.0 \mathrm{~mm}$ long and $3.5 \mathrm{~mm}$ broad. A circular funicular cavity or plug 


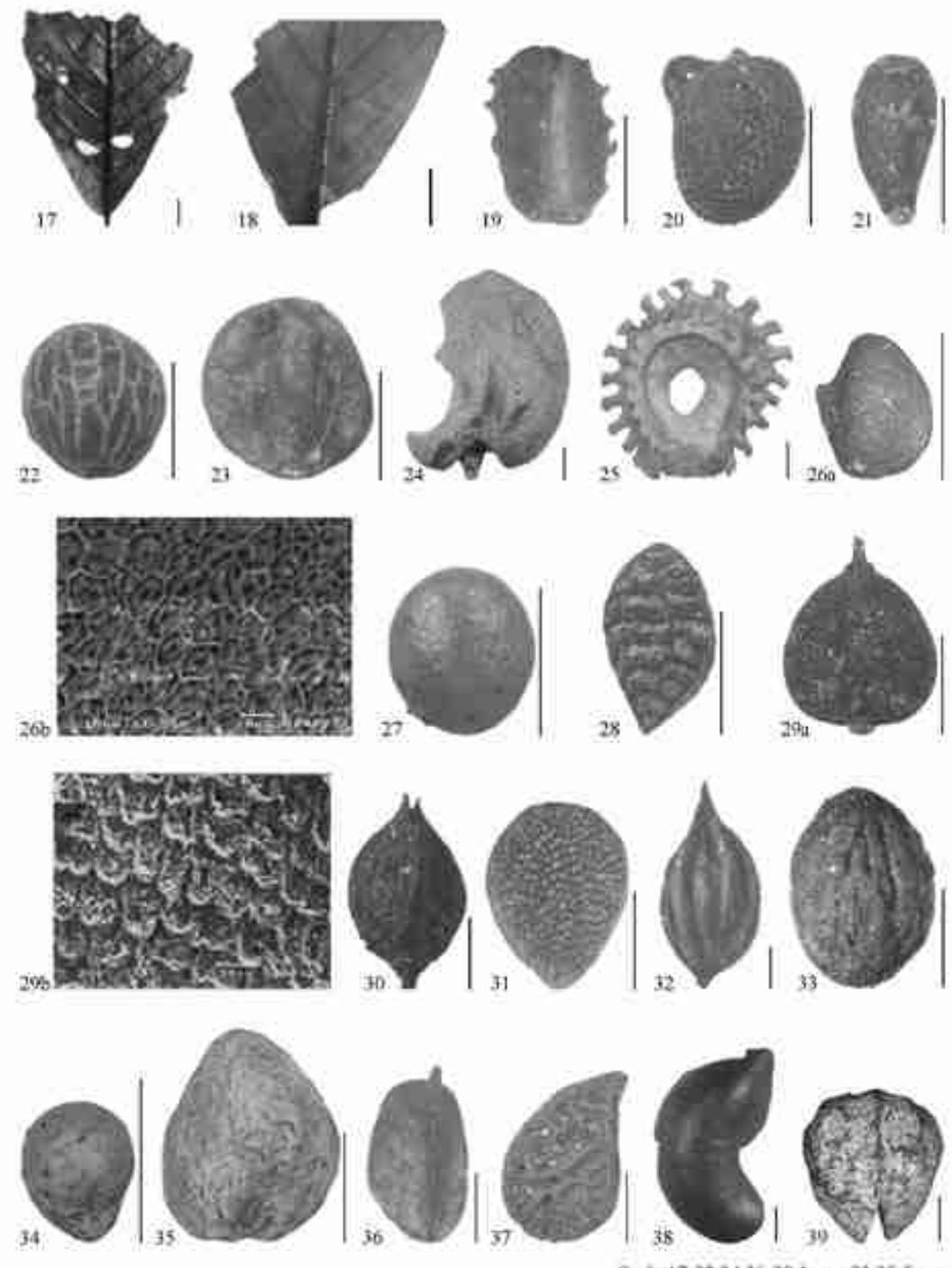

Fig. 4: 17,18. Fagaceae (leaf), 19. Myriophyllum sp. (endocarp), 20. Hypoxis aurea (seed), 21. Lycopus sp. (fruit), 22. Mosla sp. (fruit), 23. Perilla sp. (fruit), 24. Magnolia sp. (seed), 25. Stephania sp. (endocarp), 26. Ficus sp. (endocarp), 27. Nymphoides sp. (seed), 28. Oxalis sp. (seed), 29. Persicaria nepalense (fruit), 30. Polygonum sp. (fruit), 31 . Ranunculus sp. (fruit), 32. Thalictrum sp. (fruit), 33. Zizyphus sp. (endocarp), 34. Potentilla sp. (fruit), 35. Prunus sp. (endocarp), 36. Pyracantha sp. (Endocarp), 37. Rubus sp. (endocarp), 38. Rutaceae (seed), 39. Meliosma sp. (endocarp)

Scaie 17.52.34 36-30.1mm 33,35.5um

is prominent in the base. The surface of endocarp is roughly reticulate by very low ridges and a prominent median keel along the suture line. Ecology: Common in shady oak forest.

\section{Sabia sp.}

Material studied: Endocarp. The endocarp is obliquely reniform, laterally compressed, $5 \mathrm{~mm}$ long, $4.5 \mathrm{~mm}$ broad and $2 \mathrm{~mm}$ thick, bilaterally symmetrical and rounded in lateral outline. The dorsal margin is convex and basal part is concave. The surface of lateral sides is reticulate randomly with thick ribs and interspaces of reticulum are rounded polygonal. The reticulum is connivent near the funicle. Ecology:
Common in mixed and moist forest.

\section{Solanaceae}

\section{Solanum sp.}

Material studied: Seed. The campylotropous seed is circular, $2.1 \mathrm{~mm}$ long and $1.9 \mathrm{~mm}$ wide. The surface is reticulated and is composed of cells with sinuous anticlinal walls. The surface of the seed is lustrous and shiny. Ecology: Occurs in open place.

\section{Symplocaceae}

\section{Symplocos sp.}


Material studied: Endocarp. The endocarp is stony, ovoid about $5.4 \mathrm{~mm}$ long and $3.5 \mathrm{~mm}$ broad. Base truncate and apex rounded. Both base and apex bears hole. Surface is brown with minor ridges. Ecology: Occurs in sunny, shady as well as mixed oak forest.

\section{Theaceae}

\section{Eurya sp.}

Material studied: Seed. The campylotropous seeds are laterally flattened and circular to slightly angular in outline in $1.2 \mathrm{~mm}$ length and $1.5 \mathrm{~mm}$ width. The seed coat is composed of a thick sclerotic testa and a thin membranous tegmen. The outer epidermis of testa is composed of columnar cells with strongly thickened and finely pitted inner periclinal and anticlinal walls. The seeds split into two equal valves revealing a horse shoe shaped embryo cavity which curves around the condyle. Ecology: Part of the upland forest.

\section{Thymeleaceae}

\section{Daphne sp.}

Material studied: Seed. The shape of the seed is narrow, ovoid with $4 \mathrm{~mm}$ length and $2.8 \mathrm{~mm}$ width with mucronate base and obtuse to slightly truncate apex. The surface is smooth and very fine pores are distributed in order throughout the seed surface. Ecology: Occurs in shady place in temperate forest.

\section{Urticaceae}

\section{Boehmeria sp.}

Material studied: Fruit. The fruit is ovate in outline, compressed with acute styled top and obtuse base, $1.5 \mathrm{~mm}$ long, $1.0 \mathrm{~mm}$ broad. The margin is thin and winglike. The surface is lusterless and has tiny irregular relief. Ecology: Occurs on moist ravine.

\section{Verbenaceae}

\section{Verbena sp.}

Material studied: Fruit. The fruit is compressed and oblong, $1.8 \mathrm{~mm}$ long and $0.5 \mathrm{~mm}$ wide. The rounded back bears length wise ridges towards the low end and a network of cross ridges below, inner face of two planes meeting in a low ridge, the surface generally covered with whitish papillae, margin bordered by narrow flange. Ecology: Commonly occurs in open place.

\section{Violaceae}

\section{Viola sp.}

Material studied: Seed. The seed is obovoid, 1.6 $\mathrm{mm}$ long, $0.8 \mathrm{~mm}$ broad, anatropous seeds with the largest diameter close to the chalaza. The inner surface of the testa shows a transverse cellular pattern which is the characteristic feature. The seed surface is lustrous, usually indistinctly areolate. Raphe distinct, appearing as a suture or low ridge. Apex is obtuse and the chalazal area circular. Ecology: Growing as a weed on moist and open places.

\section{Vitaceae}

\section{Vitis sp.}

Material studied: Seed. The anatropous seed is obovate and compressed dorsiventrally, $4.0 \mathrm{~mm}$ long, $3.0 \mathrm{~mm}$ broad, and $2.5 \mathrm{~mm}$ thick. The micropylar part in the base of seed protrudes and is truncated. A raphe sinus runs vertically from lower part of the dorsal face into a rounded plug-like charaza in the center of the ventral face. Two lanceolate grooves are prominent at both sides of raphe in dorsal side. Ecology: Occurs in dry oak forest.

\section{RESULTS OF PLANT MACROFOSSIL ANALYSIS}

From the Dhapasi section of the Gokarna Formation 56 genera belonging to 35 families were identified which are listed in Table 1. Few unidentified taxa are also listed in the table. The taxa extracted from each fossil assemblage are listed and described according to their percentages below.

\section{Fossil assemblage DS-I}

This fossil assemblage zone is characterized by the dominance of fossil fruit and seeds of trees and shrubs over herbs. Of the trees, Eurya (39.4\%) is the most dominat taxa. Ficus (10.2\%), Carpinus (2.6\%) and Quercus $(<1 \%)$ are the common taxa. The other woody angiosperms are Alnus, Betula and Magnolia represented in minor amount. Among Gymnosperms 

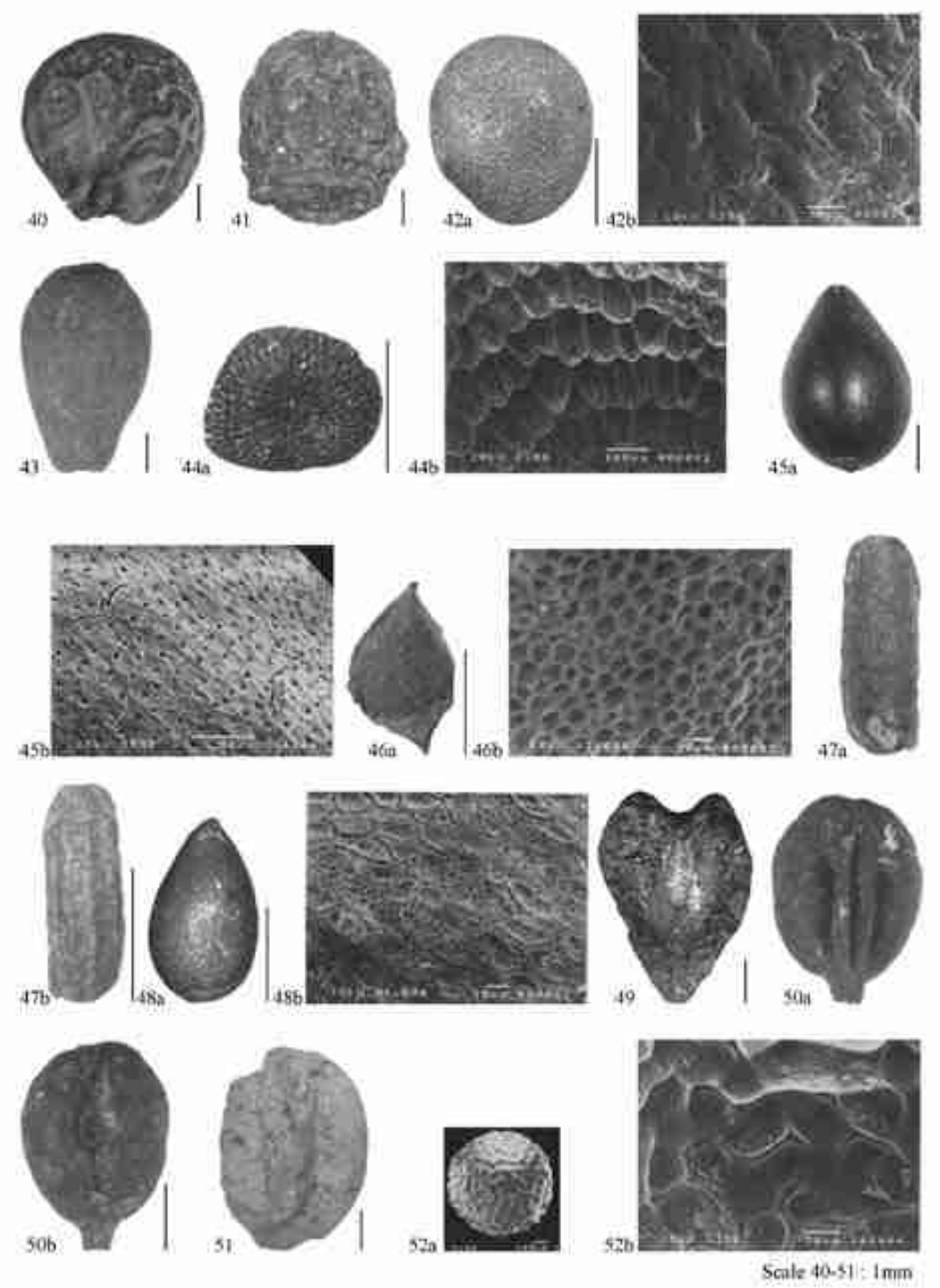

Fig. 5 : 40. Sabia sp. (endocarp), 41 Saxifragaceae (fruit), 42. Solanum sp. (seed), 43. Symplocos sp. (endocarp), 44. Eurya sp. (seed), 45. Daphne sp. (seed), 46. Boehmeria sp. (fruit), 47. Verbena sp. (fruit), 48. Viola sp. (seed), 49. Cayaratia sp. (seed), 50. Vitis sp. (seed), 51. Unknown (seed), 52. Selaginella sp. (macrospores) only Abies is included in this assemblage. Of the shrubs, Boehmeria (20.2\%) and Rubus (18.3\%) are the major taxa. The other common shrubs are Zizyphus and Pyracantha $(<1 \%)$. Actinidia, Vitis and Cayaratia are the common vines. Among the herbaceous plants, Scirpus (4.3\%), Euphorbia (2\%) are the common taxa. Lycopus, Corydalis, Polygonaceae, Oxalis, Carex etc. are the herbs represented in trace amount with less than (1\%) each. The aquatic herbs are Myriophyllum and Nymphoides.

\section{Fossil assemblage DS-II}

The herbs are the most dominant constituents in this fossil assemblage. Polygonum (19.6\%), Oxalis (13.7\%), Mosla (12.4\%) and Scirpus (11.1\%) are the most common taxa. The other common herbs are Scirpus triqueter (2.6\%), Acalypha (1.9\%), Viola (1.5\%) and Euphorbia. Of the shrubs Boehmeria (13\%), Zizyphus (5.5\%) and Rubus (3.8\%) are the dominant taxa. Phyllanthus and Symplocos are the least common taxa. Eurya, the dominantt taxa in the previous horizon declined to $(5.3 \%)$. The other common tree taxa are Quercus $(1.5 \%)$ and Carpinus (1.1\%). Alnus, Ficus, Zanthoxylum and Lauraceae are the least common woody angiosperms with less than $1 \%$ each in total count. 
Table 1: List of fossil fruit and seed from (Dhapasi section) Gokarna Formation

\begin{tabular}{|c|c|c|c|c|c|c|c|c|}
\hline Taxa & Part & DS-I (\%) & DS-II (\%) & DS-III(\%) & DS-IV (\%) & DS-V (\%) & DS-VI (\%) & DS-VII (\%) \\
\hline Abies sp. & leaf & $1(0.01)$ & & $1(0.1)$ & & & & \\
\hline Tsuga sp. & leaf & & & $1(0.1)$ & & & & $30(4.4)$ \\
\hline Actinidia sp. & seed & $8(0.1)$ & $2(0.4)$ & $18(1.3)$ & & $31(1.2)$ & $1(0.2)$ & \\
\hline Alnus sp. & fruiting scale & $22(0.4)$ & $3(0.6)$ & $4(0.3)$ & & & $1(0.2)$ & $1(0.1)$ \\
\hline Betula sp. & fruiting scale & & & & & & $1(0.2)$ & \\
\hline Carpinus sp. & nutlet & $148(2.6)$ & $5(1.1)$ & $14(1.0)$ & $2(2.5)$ & $33(1.3)$ & $50(10.9)$ & $8(1.2)$ \\
\hline Viburnum sp. & endocarp & $1(0.01)$ & & & & & & \\
\hline Cucurbitaceae & seed & $1(0.01)$ & & & & & & \\
\hline Carex sp. & fruit & $35(0.6)$ & $12(2.6)$ & $28(2.0)$ & $4(5.0)$ & $37(1.4)$ & $10(2.2)$ & $10(1.5)$ \\
\hline Eleocharis sp. & fruit & $1(0.01)$ & & & & & & \\
\hline Scirpus triqueter & fruit & $128(2.3)$ & $12(2.6)$ & $75(5.4)$ & $8(10.0)$ & $112(4.3)$ & $18(3.9)$ & $107(15.6)$ \\
\hline Scirpus sp. & fruit & $10(2.0)$ & $52(11.1)$ & $3(0.2)$ & & $9(0.3)$ & $2(0.4)$ & $2(0.3)$ \\
\hline Acalypha sp. & seed & & $9(1.9)$ & $6(0.4)$ & & $9(0.3)$ & & $13(1.9)$ \\
\hline Euphorbia sp. A & seed & $100(1.8)$ & & $20(1.4)$ & & $37(1.4)$ & $25(5.4)$ & $9(1.3)$ \\
\hline Euphorbia sp. B & seed & & $4(0.8)$ & $21(1.5)$ & & $17(0.6)$ & $4(0.9)$ & \\
\hline Phyllanthus sp. & seed & $2(0.03)$ & $2(0.4)$ & $2(0.1)$ & $1(1.2)$ & & & \\
\hline Quercus cf. Cyclobalanopsis & fruit & $19(0.3)$ & $7(1.5)$ & $7(0.5)$ & & $42(1.6)$ & $32(7.0)$ & $1(0.1)$ \\
\hline Fagaceae & leaf & $13(0.2)$ & & & & $5(0.2)$ & $16(3.2)$ & \\
\hline Myriophyllum sp. & endocarp & $8(0.1)$ & & & & & & \\
\hline Hypoxis aurea & seed & & & $1(0.1)$ & & & & \\
\hline Clinopodium sp. & fruit & & & $3(0.2)$ & & & $1(0.2)$ & \\
\hline Lycopus sp. & fruit & $70(1.2)$ & & $6(0.4)$ & & & $2(0.4)$ & \\
\hline Mosla sp. & fruit & $8(0.1)$ & $58(12.4)$ & $21(1.5)$ & $1(1.2)$ & $38(1.4)$ & $3(0.7)$ & \\
\hline Perilla sp. & fruit & $1(0.01)$ & & $10(0.7)$ & & $9(0.3)$ & & \\
\hline Lauraceae & seed & $1(0.01)$ & $1(0.2)$ & & & & $1(0.2)$ & \\
\hline Magnolia sp. & seed & $3(0.05)$ & & $1(0.1)$ & & $4(0.2)$ & & \\
\hline Stephania sp. & endocarp & $2(0.03)$ & & & & & & \\
\hline Ficus sp. & endocarp & $578(10.2)$ & $2(0.4)$ & $32(2.3)$ & $1(1.2)$ & $85(3.3)$ & & $65(9.5)$ \\
\hline Nymphoides sp. & seed & $6(0.1)$ & & $5(0.4)$ & $1(1.2)$ & $10(0.4)$ & $4(0.9)$ & $15(2.2)$ \\
\hline Oxalis sp. & seed & $3(0.05)$ & $64(13.7)$ & $8(0.6)$ & $1(1.2)$ & $7(0.3)$ & $3(0.7)$ & $78(11.4)$ \\
\hline Corydalis sp. & seed & $8(0.1)$ & & & $1(1.2)$ & $1(0.03)$ & & \\
\hline Persicaria nepalense & fruit & $6(0.1)$ & $2(0.4)$ & $40(2.8)$ & $4(5.0)$ & $31(1.2)$ & $12(2.6)$ & $14(2.0)$ \\
\hline Polygonum sp. & fruit & $18(0.3)$ & $92(19.6)$ & $39(2.8)$ & & $61(2.3)$ & $24(5.2)$ & $12(1.7)$ \\
\hline Potamogeton sp. & endocarp & & $1(0.2)$ & & & & & \\
\hline Ranunculus sp. & fruit & & & $2(0.1)$ & & & $2(0.4)$ & \\
\hline Thalictrum sp. & fruit & & & & & & & $3(0.4)$ \\
\hline Zizyphus sp. & endocarp & $8(0.2)$ & $26(5.5)$ & $3(0.5)$ & $1(1.2)$ & $46(1.8)$ & $53(11.6)$ & $1(0.1)$ \\
\hline Potentilla sp. & fruit & & & & & $12(0.5)$ & $1(0.2)$ & \\
\hline Prunnus sp. & endocarp & & & & & & $3(0.7)$ & \\
\hline Pyracantha sp. & endocarp & $4(0.1)$ & & $120(8.7)$ & $14(17.3)$ & $281(10.8)$ & $65(14.2)$ & $47(6.8)$ \\
\hline Rubus sp. & endocarp & $1035(18.3)$ & $18(3.8)$ & $350(25.4)$ & $10(12.3)$ & $239(13.0)$ & $47(10.3)$ & $55(8.0)$ \\
\hline Zanthoxylum sp. & seed & & $1(0.2)$ & & & & & \\
\hline Rutaceae & seed & $2(0.03)$ & & $2(0.1)$ & & $8(0.3)$ & $2(0.4)$ & $12(1.7)$ \\
\hline Meliosma sp. & endocarp & $4(0.1)$ & & $2(0.1)$ & & $1(0.03)$ & $1(0.2)$ & $1(0.1)$ \\
\hline Sabia sp. & endocarp & $1(0.01)$ & & & & & $1(0.2)$ & \\
\hline Saxifragaceae & fruit & & & & & & $1(0.2)$ & \\
\hline Solanum sp. & seed & $3(0.05)$ & & & & $2(0.06)$ & & $1(0.1)$ \\
\hline Symplocos sp. & endocarp & $1(0.01)$ & $1(0.2)$ & & & $1(0.03)$ & & \\
\hline Eurya sp. & seed & $2230(39.4)$ & $25(5.3)$ & $350(25.4)$ & $23(28.4)$ & $1130(43.4)$ & $35(7.6)$ & $81(11.8)$ \\
\hline Daphne sp. & seed & & & $6(0.4)$ & & $14(0.5)$ & $5(1.1)$ & $6(0.9)$ \\
\hline Boehmeria sp. & fruit & $1145(20.2)$ & $61(13.0)$ & $160(11.6)$ & $7(8.6)$ & $167(5.3)$ & $30(6.6)$ & $90(13.1)$ \\
\hline Verbena sp. & fruit & & & $7(0.5)$ & & $2(0.06)$ & & $10(1.5)$ \\
\hline Viola sp. & seed & $4(0.1)$ & $7(1.5)$ & $6(0.4)$ & $1(1.2)$ & $11(0.4)$ & & $3(0.4)$ \\
\hline Cayratia sp. & seed & $4(0.1)$ & & $2(0.1)$ & & & $2(0.4)$ & \\
\hline Vitis sp. & seed & $10(0.2)$ & & & $1(1.2)$ & $6(0.2)$ & & \\
\hline Unknown & seed & $1(0.01)$ & & & & $5(0.2)$ & & \\
\hline Selaginella remotifolia & macrospore & $1(0.01)$ & & & & & & $11(1.6)$ \\
\hline Total count & & 5656 & 468 & 1380 & 81 & 2605 & 458 & 686 \\
\hline
\end{tabular}




\section{Fossil assemblage-DSIII}

The shrubs are the dominant constituents with high percentage of Rubus $(25.4 \%)$. The other important shrubs are Boehmeria (11.6\%), Pyracantha (8.7\%), Euphorbia (3\%) and Zizyphus $(<1 \%)$. This horizon is again characterized by the increase in Eurya (25.4\%). The other common tree taxa in this zone are Ficus, Carpinus, Quercus and Alnus. Gymnosperms taxa such as Abies and Tsuga are available in minor amount. The herbaceous plants are Scirpus (5.4\%), Carex (2\%), Polygonum (2\%) and Mosla (>1\%). Lycopus, Perilla, Oxalis, Viola and Scirpus are the herbaceous taxa present in small amount.

\section{Fossil assemblage-DSIV}

This fossil assemblage is not so rich in the preservation of macro fossils. The arboreal constituents are Eurya (28.4\%), Carpinus (2.5\%) and Ficus (1.2\%) in the total count. Among the shrubs, the most dominant taxa are Pyracantha (17.3\%), Rubus (12.3\%), Boehmeria (8.6\%), Phyllanthus and Zizyphus with $(1.2 \%)$ each. There is an abruptly decrease in the herbaceous plants in this horizon. The notable herbs are Scirpus triqueter (10\%), Persicaria nepalense and Carex (5\%) each. The other common herbs are Oxalis, Mosla, Corydalis, Viola and aquatic herb Nymphoides with (>1\%) each.

\section{Fossil assemblage-DSV}

In this fossil assemblage, Eurya (43.4\%) is the most dominant taxa. The other common woody angiosperms are Ficus (3.3\%), Quercus subgen. Cyclobalanopsis (1.6\%) and Carpinus (1.3\%). Magnolia $(<1 \%)$ is also the notable taxa. The leaf remains of Fagaceae are also extracted from this horizon. Of the shrubs, Rubus (13\%), Pyracantha (10.8\%), Boehmeria (5.3\%) and Zizyphus (1.8\%) are the important taxa. The other notable constituents are Euphorbia (1.4\%) and Vitis ( $<1 \%)$. Scirpus triqueter (4.3\%) and Polygonaceae (3\%), Mosla, Actinidia and Carex with $(>1 \%)$ each are the common herbaceous taxa. Oxalis, Viola, Acalypha with $(<1 \%)$ each are represent in minor amount.

\section{Fossil assemblage-DSVI}

This fossil assemblage is characterized by the abrupt decline in Eurya to $(7.6 \%)$ but there was increase in the constituents of other woody angiosperms. Carpinus (10.9\%), Quercus subgen. cyclobalanopsis (7\%), and some indetermined leaves of Fagaceae $(3.3 \%)$ are the principal constituents. Alnus and Betula, Lauraceae and Prunus with each $(<1 \%)$ are also the notable taxa. Ficus is totally absent in this horizon. Of the shrubs, Pyracantha is to its maximum with (14.2\%), Zizyphus (11.6\%), Rubus $(10.3 \%)$, Boehmeria $(6.6 \%)$ are the dominant taxa. The other common shrubs are Daphne (1.1\%), Sabia and Cayratia with $(<1 \%)$ each. Of the herbs, Polygonaceae (7.8\%), Euphorbia (6.3\%), Scirpus triqueter (3.9\%) and Carex (2.2\%) are the principal constituents. The other common herbs are Nymphoides (1\%), Perilla, Oxalis, Ranunculus, Lycopus etc. with $(<1 \%)$ each.

\section{Fossil assemblage-DSVII}

There was major change in this fossil assemblage with the reappearance of Gymnosperm taxa. Tsuga $(4.4 \%)$ is the major conifer. Of the woody angiosperms, Eurya (11.8\%) was the major constituents but had declined than that of the previous horizon. Ficus (9\%) and Carpinus (1.2\%) are the other common arboreal elements. Quercus and Alnus are the least common taxa with $(<1 \%)$ each. Of the shrubs, Boehmeria (13.1\%), Rubus (8\%), Pyracantha $(6.8 \%)$, Rutaceae $(1.7 \%)$ are the major constituents. The other common shrubs are Zizyphus and Daphne with $(<1 \%)$ each. Of the herbaceous plants Scirpus triqueter (15.6\%), Oxalis (11.4\%), Polygonaceae (3.7\%), Carex (1.5\%) and Euphorbia (1.3\%) are the main contributors. The other less common herbs of this horizon are Acalypha, Solanum, Viola, Thalictrum etc. Nymphoides $(2.2 \%)$ and Verbena $(1.5 \%)$ are the common aquatic herbs. Selaginella remotifolia $(1.6 \%)$ is also the notable pteridophytes.

\section{PALAEOCLIMATIC INTERPRETATION}

Owing to different sand and clay facies the macrofossil assemblages are biased by taphonomical processes. The richness of the fossil in one horizon and less in immediate next horizon certainly not present the complete picture of the floral composition at that time. However taking the face value we can say something about the plant growing around the depositional basin during the time of Gokarna 
Formation. The representation of Eurya throughout the horizon and the common occurrence of Quercus subgen. Cyclobalanopsis indicates that the lucidophyllous forest was dominated in the Kathmandu Valley during the time of the deposition of this section. Kathmandu Valley is situated in the western limit of the lucidophyllous forests that developed under the humid and warm temperate East Asian monsoon climate.

From the result of plant macrofossil analysis, Eurya was the most dominant taxa throughout all the macrofossil assemblages. Likewise Rubus, Ficus, Pyracantha, Carpinus, Zizyphus, Quercus subgen. Cyclobalanopsis, Alnus, Boehmeria were the other important arboreal constituents in those assemblages. The herbaceous taxa contained mostly the wetland and floodplain elements like Carex, Scirpus spp., Ranunculus, Nymphoides, Myriophyllum. The conifers such as Abies and Tsuga were represented in minor amount.

In order to reconstruct the palaeoclimate around the depositional basin we used some of the important macrofossils as the main indicators of palaeoclimate. Eurya, the important taxa throughout the assembalges was one of the key genera to infer the subtropical climate, Quercus subgen. Cyclobalanopsis as warm temperate climate and Alnus as wet climate. Pyracantha, Carpinus, Ficus and Zizyphus were the other important taxa to show subtropical to warm temperate climate. Abies, Tsuga and Betula were the taxa to show the cold climate. The occurrence of subtropical and warm temperate taxa including Eurya, Rubus, Ficus, Pyracantha, Carpinus, Quercus subgen. Cyclobalanopsis and Zizyphus throughout macrofossil assemblages indicated that such climate continued during the depositional period of the Dhapasi section. However change in the constituents of those taxa and appearance of elements such as Abies, Tsuga and Betula indicate shifting of climate to relatively cooler phase around the depositional basin.

A detail palynological study was also performed from the same section of Dhapasi (Paudayal, 2006). By the dominance of Gymnosperm taxa such as Pinus, Picea, Abies and Tsuga over woody angiosperms (Quercus, Castanopsis) in the lowermost horizon of this section indicated the cold temperate climate. With the drastic increase in the subtropical to warm temperate element Castanopsis and Quercus and decrease in Gymnosperm taxa, the middle horizons revealed the most warm phase during the deposition of the Gokarna Formation. The reappearance and the dominance of Gymnosperm taxa to woody angiosperms in the upper horizons suggested the shifting of subtropical-warm climate to cold temperate climate. Pinus was the most dominating Gymnosperm taxa along with Abies, Picea and Tsuga. Deciduous taxa such as Betula and Ulmus were also present. Quercus was the most dominant woody angiosperm. Castanopsis, the subtropical element gradually decreased and disappeared towards the top (Paudayal, 2006).

Comparing the result obtained from the pollen and paleocarpological analysis, we were not able to get the similar interpretation. Most of the important taxa represented in palynological assemblage were from the very high altitudinal range. Pinus wallichiana, Abies, Tsuga, Picea are the elements growing in the altitudinal range of $2000-4400 \mathrm{~m}$ and these were the dominant taxa throughout the pollen zones. The gymnosperms and also some angiosperms produce large number of pollen which easily carried to long distance by wind. Such long distance pollen were derived from higher altitude and deposited in the basin. However the macrofossils represented in fossil assemblages are in situ elements and give the impression of local vegetation growing around the depositional basin.

\section{CONCLUSION}

The macro-fossils of the Dhapasi section revealed seven fossil assemblages consisting 35 families with 56 genera which were described according to their morphological characteristics. The characteristic feature of the Dhapasi section (Gokarna Formation) is the dominance of woody angiosperms over the gymnosperm taxa. The constant occurrence of Eurya, Rubus, Ficus, Pyracantha, Carpinus, Quercus subgen. Cyclobalanopsis and Zizyphus indicated that subtropical to warm temperate climate throughout the section. However change in the constituents of those taxa and occurrence of cooler elements like Abies, Tsuga and Betula may indicate minor fluctuation of climate around the basin during the deposition of the Gokarna Formation. 


\section{ACKNOWLEDGEMENTS}

We thank Faculty of Horticulture, Chiba University and Paleo-Labo Company, Saitama, Japan for providing facility to use the LM and SEM. We should like to thank Dieter Uhl (Senckenberg Research Institute, Frankfurt, Germany), Edoardo Martinetto (University of Torino, Italy) and Krishna K. Shrestha (Tribhuvan University, Nepal) for their suggestions for improving the manuscript. This research is partly supported by the grant from Nepal Academy of Science and Technology (NAST).

\section{REFERENCES}

Dangol, G. M. S., 1985. Geology of the Kathmandu fluviatile lacustrine sediments in the light of new vertebrate fossil occurrences. Jour. Nep. Geol. Soc., v. 3 , no. 1 , pp. $43-57$.

Fujii, R. and Sakai, H., 2001. Paleoclimatic changes during the last 2.5 myr recorded in the Kathmandu Basin, Central Nepal Himalayas. Jour. Asian Earth Sci., v. 20, pp. 255-266. doi:10.1016/S1367-9120(01)00048-7

Gajurel, A. P., France-Lanord, C., Huyghe, P., Mugnier, J. L., Sakai, T., Sakai, H. And Upreti, B. N., 2007. Dry climatic evidence in Central Himalaya around $40 \mathrm{ka}$ from lacustrine sediments of Kathmandu Basin, Nepal. Jour. Nep. Geol. Soc., v. 36 (Sp. Issue), pp 4-5.

Igarashi, Y., Yoshida, M. and Tabata, H., 1988. History of Vegetation and Climate in the Kathmandu Valley. Proc. Indian Natn. Sci. Acad., v. 54A, no. 4, pp. 550-563.

Malla, S. B., Shrestha, A. B., Rajbhandary, S. B., Shrestha, T. B., Adhikari, P. M. and Adhikari, S. R., (Eds.), 1976. Flora of Langtang and cross section vegetation survey (central zone). Bulletin of the Department of Medicinal Plants, 269p.

Malla, S. B., Rajbhandary, S. B., Shrestha, T. B., Adhikari, P. M., Adhikari, S. R. and Shakya, P. R., (Eds.), 1986. Flora of Kathmandu Valley. Bulletin of the Department of Medicinal Plants, No.11.

Nakagawa T., Yasuda Y. and Tabata H., 1996. Pollen morphology of Himalayan Pinus and Quercus and its importance in palynological studies in Himalayan area. Review of playobotany and Palynology, v. 91, pp. 317-329.

Paudayal, K. N., 2002. The Pleistocene Environment of the Kathmandu Valley, Nepal Himalaya. An unpublished Ph.D. thesis submitted to institute of Palaeontology, Faculty of Natural Sciences, University of Vienna, Austria, 157p.

Paudayal, K. N. and Ferguson, D. K., 2004. Pleistocene Palynology of Nepal. Quaternary International, v. 117, pp. 69-79. doi:10.1016/S1040-6182(03)00117-4

Paudayal, K. N., 2005. Late Pleistocene Pollen Assemblages from the Thimi Formation, Kathmandu Valley, Nepal. The Island Arc, v. 14, no. 4, pp. 328-337. doi:10.1111/j.1440-1738.2005.00490.x

Paudayal, K. N., 2006. Late Pleistocene Pollen Assemblages from the Gokarna Formation, Kathmandu Valley, Nepal. Jour. Nep. Geol. Soc., v. 33, pp. 33-38.

Press, J. R., Shrestha, K. K, and Sutton D. A., 2000. Annonated Checklist of Flowering Plants of Nepal, British Museum of Natural History, London.

Sakai, H., Fuji R., Kuwahara, Y., Uprety B. N. and Shrestha S.D., 2001. Core drilling of the basin fill sediments in the the Kathmandu Valley for paleoclimatic study: preliminary results. Jour. Nep. Geol. Soc., v. 25 (Sp. Issue), pp. 9-18.

Stainton, J.D.A., 1972. Forests of Nepal. John Murray, London, 181p.

Takhtajan, A., 1986, Floristics regions of the world. Univ. California Press, Berkeley, 522p.

Worobiec. G., 2003. An improved technique for separation, bleaching and preparation of slides from fossil leaf compressions. Review of Palaeobotany and Palynology v. 126, pp. 1-5. doi:10.1016/S0034-6667(03)00008-3

Yoshida, M. and Gautam, P., 1988. Magnetostratigraphy of Plio-Pleistocene lacustrine deposits in the Kathmandu Valley, Central Nepal, Proc. Indian Natn. Sci. Acad., v. 54A, no. 30, pp. 410-417.

Yoshida, M. and Igarashi, Y., 1984. Neogene to Quaternary Lacustrine sediments in the Kathmandu Valley, Nepal. Jour. Nep. Geol. Soc., v. 4, pp.73-100. 